\title{
sciendo
}

Ethics \& Bioethics (in Central Europe), 2021, 11 (3-4), 126-141

DOI:10.2478/ebce-2021-0019

\section{On the safety and danger of 'viral' information from the perspective of the epistemological subject}

\author{
Peter Gurský1
}

\begin{abstract}
The present paper addresses the formal perspective of information with the focus on 'untrue' information presented as dangerous. Grounded in perspectivism, the epistemic subject is understood as decisive in informational transfer. In this context, ethics should focus on how the epistemic subject receives information. Regarding wide-spread information, the notions of danger and safety, the latter being a reaction to the former, essentially result from the fear mechanism of affective neural systems in higher mammals. The practice of attaining safety by eliminating danger is analyzed through the Nietzschean metaphor of the Apollonian and the Dionysian and the concept of ressentiment. Focusing on the individual, the paper presents a critique of systemized authoritative management of speech content, intensified by the emergence of social media. It is asserted that, by reacting to danger through the systematization of prevention and regulation of speech, it not only affirms fear but also decreases the faculties of an individual to deal with danger and fear itself. The paper argues that the only way to overcome danger and fear is through the individual's exposure to it, which allows for the strengthening of one's faculties, thus fulfilling one's potential in freedom.
\end{abstract}

Keywords: authority, COVID-19, danger, epistemology, information, Nietzsche, perspectivism safety, speech, subject

\section{Introduction}

"Scientists have discovered an accessible drug for COVID, according to the study, it reduces the risk of death by 80\%" (Zem \& Vek, 2021). The headlined article was published in January 2021 and contains the testimony of a Slovak physician of a promising COVID-19 patient treatment by zinc, vitamin C, aspirin, calcitriol, and ivermectin. Towards the end of the article, there is a notice that most of the scientific community is skeptical about the effect of ivermectin on COVID-19 patients and expects further research. At the very end, it is claimed that "[i]t is clear why the scientific community funded by the pharma lobby is questioning a cheap drug, since the vaccine will bring incalculable profits" (Zem \& Vek, 2021). In February 2021, the Slovak Ministry of Health informed the public about the approval of a significant increase of ivermectin supply to Slovak pharmacies (Ministry of Health of the Slovak Republic, 2021a; 2021b). In March, the European Medicines Agency advised "against use of ivermectin for the prevention or treatment of COVID-19 outside randomised clinical trials" (European Medicines Agency, 2021). In July, the findings of the original research concluding the positive effectiveness of ivermectin on COVID-19 patients (Elgazzar et al., 2020/2021) were disputed and the study was retracted (MedPage Today, 2021). In those and following months, there was a significant growth in the number of patients suffering from ivermectin side-effects or ivermectin overdose (TV Markíza, 2021), among which is sterility in men (Idonije et al., 2011), ${ }^{2}$ coma, and death (The Centers for Disease Control and Prevention, 2021).

\footnotetext{
${ }^{1}$ University of Prešov (Slovakia); peter.gursky@smail.unipo.sk; ORCID: 0000-0003-4307-343X

2 The claim about the sterilization effect of ivermectin in men is, however, undergoing discussion regarding the validity of the methods used. USA Today rates the study as "false" (USA Today, 2021).
} 
In the last, approximately, 10 years, so-called new media experienced a rapid growth in their user databases. ${ }^{3}$ During those years, these platforms became the standard means of communication (both peer-to-peer and via institutional representative pages, including legacy media) which meant the expansion of user-created content to such a degree that it escaped the state of controllability. This phenomenon became unsettling to the controlling powers (mainly at government level) since the reach of an average user's speech became significantly more impactful. The reason for this was that the potential danger exceeded what was previously understood as the danger of 'free speech'.

In 2005, the Slovak government passed the law in which it became forbidden for a citizen to spread such information that is untrue and as such causes danger for and/or agitation of the part of the public. The subsequent paragraph of the law extends the definition during a national (state) crisis also to the act (of speech) in negligence (Zákon č. 300/2005; § 361-362). Whether the law was defined effectively or not, it did not anticipate the complex situation of speech entering online, corporate-owned ground. After the 'boom' of these platforms, governments started to generate pressure on those companies with the goal of improving control over online speech. In doing so and with the acknowledgment that the governments cannot control speech on private grounds directly, it led to an increase in private control over their content. Every registered user of any social media grants consent to the platform's policies. Those policies, although ordinarily including the policy of abiding to the legislation of the country of origin of the user's online action, are set by the company with no strict correlations with the law of the company's country. However, in connection with recent data leaks and Facebook Papers (2021), the governments of multiple countries increased the pressure put on social platforms to assume more responsibility for the content. It should be obvious that the before-mentioned growth of user count created a kind of a content bandwidth that is at least as difficult to control as it is to deal with 'offline' criminal activity. The increase in the number of employees dealing with content control, AI bots seeking banned content, or even allowing users to report content that does not follow a given platform's policies, helped control over the content only to some extent, ${ }^{4}$ however, such a motion made private subjects more powerful in respect to the control of online speech than European governments. The war of private and public sectors over online speech control has changed its narrative during the last 10 years, which could be represented by the carefully-thought utterance by the European vice president for the digital single market, Andrus Ansip: "We need to find a balanced approach between the [sic] freedom of expression, media pluralism and a citizen's right to access diverse and reliable information [...] All the relevant players like online platforms or news media should play a part in the solution" (European Commission, 2017). It could be concluded that there is an empirically traceable trend that some politically influential European governments having a problem controlling online speech prefer to make private companies more powerful over speech than to have no control at all. This would imply that the need to control speech can be as valuable as is the son to his rightful mother in the Judgement of Solomon. However, why would it be so valuable?

\footnotetext{
${ }^{3}$ In 2011, Facebook surpassed 500 million monthly active users, Twitter and the Russian social network VKontakte reached 100 million. In the years 2009-2011 many other social media entered the market including Pinterest, Instagram, Quora, Snapchat, and Twitch, representing some of today’s most used platforms.

${ }^{4}$ See Howard (2020) and Constine (2017).
} 
The European Commission justifies the development of EU initiatives ${ }^{5}$ to generate activity towards better control of information by the notion that disinformation - "verifiably false or misleading information created, presented and disseminated for economic gain or to intentionally deceive the public" (European Commission, 2021) - can lead to "threatening our democracies, polarising debates, and putting the health, security and environment of EU citizens at risk" (European Commission, 2021). Setting the morality of the act of creating a 'disinformation' aside, the (re)action towards speech control is set in motion by an (acute or potential) awareness of danger. It could (and should) be examined, in another paper, how adequate the fear of the danger is and to what extent the presumption of the possible danger is adequate, but for now, let us focus on the formal side of the phenomenon.

\section{Information}

Firstly, let us base our investigation on the supposition that existence is. As such, existence must be comprised of everything that exists. Everything in existence for it to be must exist in a certain way and not another. Therefore, for existence itself to $b e$, it must exist in a certain way and not another. The way existence is, is the formation of things. Let us call this formation information. If the nature of existing things is defined by how they are in existence, then existing things themselves are information. Everything that exists is therefore information. In this way, things as information are in relation to information as such in the same way as the existing things are in relation to existence as such. Information has, in this way, a co-dependent relationship with existence, which means that every piece of information pertains only to existence and nothing else. For this reason, when considering any piece of information, the answer to the question of the described existence in the piece of information is always positive, therefore the question is invalid. To examine information, existence is a necessary presupposition and not in question, but the manner in which the existence related to the examined piece of information exists is decisive for our further evaluations regarding the relationship between a certain piece of information and a certain existence.

Now, let us consider a recipient of information - the epistemic subject. If the epistemic subject exists, he must exist in a certain way. It also follows that the epistemic subject, being in existence but not being existence as such, is also a sum of certain kinds of information, but not information

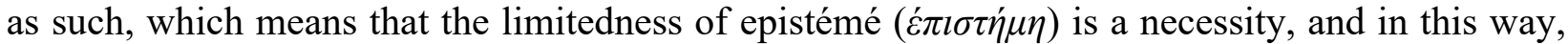
the epistemic subject has a limited access to information due to his very nature. Let us focus more on the nature of the epistemic subject. The uniqueness of the subject as a thing in existence is identical to its information. The specificity of the epistemic subject constitutes the manner in which information (in this context epistémé) is obtained. This specificity can be understood as a concrete subjectivity, i.e., a quality of epistemic means by which a set of information obtains new information. In this way, the epistemic subject obtains only information about the information of existing things. If the epistemic subject wills to obtain true information about existence, he must tailor his epistemic means in such a manner that allows such obtainment. In any way, the epistemic subject carries information due to his nature; this set of information correlates with (/is adequate to) either the information about the existence of things or the subject as a set of information. In making claims, we refer to information of some existence. However, since subjectivity carries a specific set of information due to the nature of the epistemological subject, in dealing with such

\footnotetext{
5 Code of Practice on Disinformation (2018), European Digital Media Observatory (2018), Tackling online disinformation: a European approach (2018), European Democracy Action Plan, COVID-19 disinformation monitoring and reporting programme (2020), and other.
} 
information we must always take the factor of subjectivity into consideration. The extra value of subjectivity regarding information is perspective. Existence is objective, but the epistemic subject carries information in perspectives, ergo is subjective. The perspective of epistemic subject consists of information about information, i.e., a mode in which information of existence exists in a subjective mode, ergo a concrete mind. For a concrete perspective to be true not only to a concrete subjectivity, but also to the existence, it must be in congruence with information of existence. For this reason, the main ethical interest should be in exploration and correction of the manner in which the subject receives information from the existence, in other words, the main epistemological and ethical issue lies in formation of the information of information of existence, i.e., the subjective (secondary) level of obtaining information.

In this context, let us consider the following propositions of epistemological perspectivism: 1) there is a world outside the mind that can be seen in different perspectives; 2) perspectives reveal the world; 3) all views occur in some perspective; ${ }^{6} 4$ ) perspectives qualitatively differ in validity since we are able to compare perspectives to one another (Miner, 2017, p. 64). ${ }^{7}$ The first two claims about the world outside the mind are compatible with the views provided by this study, and as such, they provide the validity dimension towards the (objective) world. The third proposition is a manifestation of the limitedness of the epistemic subject, since all information is accessible to the epistemic subject only as information about information, as argued before. The fourth proposition presents us with factors by which a perspective can be assessed, but only in comparison to another. Perspectives can be compared through the perspective of coherency, logic, aesthetics, capacity, utility, effects, etc. In this way, in order to gain reliable knowledge, a piece of information must be viewed in relation to other information, or as Nietzsche puts it: "[a]n isolated judgment is never 'true', never knowledge; only in the connection and relation of many judgments is there any surety" (Nietzsche, 1968, p. 287; WP 530). ${ }^{8}$

\section{Untrue information}

Now, let us look at some of the most used concepts in contemporary discussions on the possible danger of information. There is an ongoing tendency to view meaning through the prism of intentionality, with the bases in the theory of mind (Brentano, 2015; Crane, 1998; 2009; Perry, 1994), particularly through the theory of consciousness (Dennett, 1987), philosophical psychology (Premack \& Woodruff, 1978), phenomenology (Bayne \& Montague, 2011), epistemology (Loewer, 1987; Zalta, 1988), and ethics (Anscombe, 2000). In the context of semantics, P. Grice (1957) demonstrated that in ordinary language we use meaning in two senses: natural meaning and non-natural meaning. The latter, being of his primary focus, is in what was later called intentionbased semantics explained from the perspective of intentionality (Grice, 1957; 1975). S. O. Søe, following Grice's research, presents three kinds of non-natural information: intentionally nonmisleading information; unintentionally misleading information - misinformation; intentionally misleading information - disinformation (Søe, 2019). In this way, the factors of the perspective are intent and verity. We find general acceptance in a definition of disinformation that includes an intention to deceive. ${ }^{9}$ Zimmerman and Kohring, however, claim that we can condition the

\footnotetext{
6 "[...] facts is [sic] precisely what there is not, only interpretations" (Nietzsche, 1968, p. 267; WP 481).

${ }^{7}$ Miner, as paraphrased, provides the components of perspectivism as inversions of the claims provided by Leiter (1994, p. 344).

${ }^{8}$ See also another passage: "There is only a perspective seeing, only a perspective "knowing"; and the more affects we allow to speak about one thing, the more eyes, different eyes, we can use to observe one thing, the more complete will our "concept" of this thing, our "objectivity," be" (Nietzsche, 1967, p. 119; GM III/12).

${ }^{9}$ See the discourse analysis by Jaster \& Lanius (2021); see also Fallis (2015).
} 
definition of disinformation either by intention to deceive or by disregard for truth (Zimmerman \& Kohring, 2018). Such a definition of disinformation is criticized as "highly idiosyncratic" (Jaster \& Lanius, 2021, p. 35), since the bullshit dimension (Frankfurt, 2005) is generally ascribed to misinformation (Søe, 2019; Pritchard, 2021), and the intent to deceive is attributed to disinformation (Fallis, 2015; Fallis \& Stokke, 2017) and fake news (Dentith, 2016; Rini, 2017; Jaster \& Lanius, 2021; Gelfert, 2021; Zimmermann \& Kohring, 2021).

We can find a similar problem of definition within the discussion about the above-mentioned fake news. By a small meta-analysis of fake news definitions provided by Jaster \& Lanius (2021) we find that most of the theorists subjected to the analysis agree on the truth, deception, and bullshit dimensions in defining fake news, which means that in pursuit of consensus in defining fake news we would have to take into account that fake news is untrue and misleading and/or is intended to deceive and/or that distributors of fake news are indifferent to the truth (Jaster \& Lanius, 2021). Fake news viewed in these terms overlaps with both misinformation and disinformation, as categorized by Søe, although the sum of both does not constitute fake news itself, since it would be identical to untrue information. In this context, Jaster \& Lanius (2021) point out that in journalism, it is becoming more common to use the term disinformation instead of fake news. It is often overlooked, however, that the truth dimension itself is not necessarily decisive for a piece of information to be fake news, since some effective forms of fake news do not contain an explicit untruth, but they omit some relevant contexts (Gelfert, 2018; 2021; Pritchard, 2021).

From the previously stated, it should be clear that the conceptual set in the discussion about possible danger of information is not clear at all. A first set of problems arises from the understanding of intentionality. From the semantic point of view, intentionality is a presupposition of sense of any given sentence. A sentence is a representation of its reference (a thing in existence), but not the reference itself (neither the thing nor existence themselves). Without the intention dimension, a sentence could be read only through means of linguistics in a restricted sense (i.e., syntax and morphology). Although, to presuppose the intention of a sentence, i.e., that the sentence has a meaning at the sentence level, allows for understanding of what the sentence means, i.e., in what way the sentence is to be understood. In this way, every unit of morpheme, word, phrase, clause, and sentence carries a specific meaning, different at every level. From the semantic point of view, a proposition itself cannot carry the intent to deceive, since the intent of the proposition is expected and necessary to be known for the intended understanding - understanding presupposes intention. It means that no proposition can be deceitful in itself, since if the proposition is understood as intended, the deception perishes.

When we talk about the intent to deceive, then we talk about a psychological-ethical state of mind, where the intent to deceive represents a motive of the moral agent regarding the intent of the meaning of the expressed proposition. The intent to deceive on ethical grounds means the intent to lie, i.e., a possibility not to allow access to a given piece/set of information to other recipients of information (i.e., other minds), upon which the moral agent is willing to act, via means of information. A moral intent to deceive thus represents a non-identical relationship between the semantic meaning of a given proposition and the information carried by the originator of the proposition. Vice versa, an endeavor to establish an identical relationship between meaning and knowledge represents an intent to be honest.

The dimensions of intent to deceive and disregard the truth arise from an omniscient perspective which presupposes certain kinds of knowledge that are obtainable only by an extra set of information apart from the original evaluated piece of information. To see this, let us consider a subjectivistic perspective. When a subject is presented with a piece of information, the intent to deceive and disregard for truth become one category - the unknown. There is no reliable method 
of gaining knowledge about the content of the motives and relationships to the truth of originators of any information. We can make claims about the verity of given information, which are as good as our epistemological abilities are, but to ascribe certain qualities to motives and relations, which are by nature truly transcendent to the subject (when it comes to other subjects), is nothing but our limited judgement based on the present effects of our subjective set of information, i.e., on $u s$, with the questionable presupposition of existence of given moral facts in the world.

It is not clear in what ways the intent to deceive and disregard for truth are treated as epistemological dimensions. The above-mentioned connections of epistemological and ethical dimensions of certain kinds of perspectives on information present a specific set of problems. When confronted with a piece of information we later evaluate as untrue, the information about the untruth of the piece of information tells us nothing about the motive or the relationship to the truth of the originator. However, what is more important is that, even if we could reliably assess the un/intentionality of spreading untrue information, it tells us absolutely nothing about the morality of the action, since it would require a presupposition of existence of the moral fact that to lie is always morally bad/wrong. In considering the verity dimension, by acknowledging the subjective character of our epistemological judgements about information from other subjects, we must acknowledge the complexity of subjectivity of the originator of a given piece of information.

For these reasons, the paper will not focus on the intent and bullshit dimension, since the true knowledge about both intent and verity is obscured by the requirement for an extra set of knowledge. To avoid the terminological confusion described earlier, the paper will, for the subjectivistic perspective, use the term information in the sense of language claims that carry meaning in correspondence with a set of shared language rules and about which we have no knowledge of verity, intent, and relation to the truth of the originator, and the terms untrue and dangerous information, which we consider not true and dangerous by a subjective judgement.

\section{On the notion of control and safety}

The need to control (other people and their actions) comes both from affects of the mind (in this case by fear) and rationality (as a reaction to the affect). The unpleasant affect triggers the mind to identify the unpleasant affect as a problem that is as such categorized as a problem for rationality, shifting the energy from a passive feeling to action based on the passive feeling. ${ }^{10}$ One of the most basic reactions to fear (other than flight) is to eliminate the source (i.e., object, or stimulus) of the fear. ${ }^{11}$ Since a living human agent is essentially in control of the self (and only to a variably limited extent) and learns to only indirectly 'control' the behavior of other people through social learning (albeit this too varies greatly), the aim to 'control' other people is to regulate the social environment in such a manner that it reduces the actual or potential danger that could decrease the chance of experiencing an affected mind. Although an undoubtedly useful mechanism that (among others) secured the survival of the human species, the fear mechanism describes the formal aspect of an affective process manifested as an actual experience of the affect of fear which is in fact itself the immediate source of the mind being bound by an affect and thus not being 'free'. An experience of intense emotions, such as fear, anger, stress or anxiety, can activate the so-called amygdala hijack, which triggers a fight-or-flight response and disables the frontal lobe, which is associated mainly with cognitive functions (Goleman, 2005). The aim of removing the fear stimuli is fundamentally the aim of removing the unpleasant affect; the removal of the fear stimuli is, from

\footnotetext{
${ }^{10}$ For a detailed description of affective mechanisms and the affected mind see the forthcoming monograph of Petrufová Joppová: Od patetiky k etike [From pathetics to ethics] (2022).

${ }^{11}$ See footnote 20.
} 
the perspective of the mind (not rationality), a mere byproduct. By killing a spider, an arachnophobe does not stop being fearful of spiders; by 'killing' potentially 'dangerous' information in the social ether one does not stop being fearful of the potential danger of 'dangerous' information.

The reasoning is this: the mind, conscious of its potential (i.e., of freedom, to a limited extent), 'feels' unfree being bound by an ongoing affect since then it becomes its subject - this unfreedom is an active resistance of the mind (using those abilities that are momentarily 'available', e.g., rationality) which leads to an action with two aims: the elimination of all fear stimuli or the elimination of all fear. It is important, however, not to forget that the process of resistance is in fact a part of the process of fear mechanism - there is no resistance (the need to control) without fear itself. It may be safe to say that neither of those aims is achievable, although in politics we tend to focus on eliminating the stimuli rather than fear itself. On the other hand, thanks to some great anthropological studies and recent neuroscience, we understand the role of fear mechanism to such an extent that we could rationally conclude that the removal of fear (mechanism) would endanger the proper regulation of the body and its being in the physical world, and as such is good for the survival of the body. ${ }^{12}$

If the notion that the need for social control arises from the need to control fear is true, then the question 'What is the desired (and perhaps good) proportion between fear and safety?' is in place. If we act on fear, our urge is to escape the object of fear or to destroy it. If we act on rationality, we act on ratio evaluating the object (ratio being motivated by the affect). The process of elimination of the affect by recognizing the object is a common method in current psychotherapy. However, it was never the objective of psychotherapy to affirm fear to such an extent that the whole procedure would aim to eliminate all fear. It is a result of the assumption that there is a 'normal' ('healthy') level of the fear mechanism functions and an 'unhealthy' level of fear reactions (the reaction level would be either too high or too low and would limit the subject in his ordinary life to a significant extent).

\section{Danger and fear}

At the political level, the notion of safety is a part of what is expected of a democratic state and its leaders. The citizen acknowledges the responsibility of the state for safety in the governmentcontrolled area as its innate function. Governments regulate weapon, drug, and service markets for this purpose. The more the authority limits the citizen's means of self-preservation and selfprotection, the more it takes the responsibility for these natural faculties. When danger emerges, the citizens of a state rightfully expect the authority to eliminate it. The effect of the responsibility shift is that citizens, not being expected to resolve danger in the areas that the authority took over, are also shielded from a large number of dangerous stimuli, which leads to a lesser concern (fear) from citizens over given areas that could be of no interest to them when not being exposed to them - the 'acute' fear from natural stimuli is veiled.

As we already established that a certain amount of fear to certain (dangerous) stimuli contributes to human self-preservation and that acting on the affect of fear does not lead to freeing the mind but rather affirms the affect, it should be obvious that the solution to this is not to eliminate fear but to overcome it. For this reason, Aristotle defines courage ( $\dot{\alpha} v \delta \rho \varepsilon i ́ \alpha)$ as a midpoint (or an equilibrium) between fear ( $\left.\delta \varepsilon \imath \lambda{ }^{\prime} \zeta\right)$ and recklessness $(\theta \rho \tilde{\alpha} \sigma o \varsigma)$ : to be courageous is to know what to fear and what not to fear (Aristotle, 2004, pp. 48-54; NE III/6-9). The archetype of the devouring mother (Jung, 2004) could be an appropriate warning of what the relationship between the

${ }^{12}$ See footnote 20. 
individual and the authority can become. The devouring mother acts on her rationally constructed idea of her love instead of acting in such a manner so that the child matures through a series of attempts to orient itself in the world, many of which are a success and many a failure. The devouring mother as an overprotective mother tries to eliminate all possible dangers to ensure absolute safety in which the child never matures. The child of the devouring mother, not being exposed to fear stimuli, never understands fear and how to process it, so it never becomes courageous. The child remains weak and dependent on the mother who fought every danger instead of the child. Although the world is too complex to fit the metaphor perfectly, it speaks a simple truth: overprotection does harm. To seek refuge in safety at all costs means to find the weakness. To seek danger at all costs, however, often leads to death. So, the true strength of an individual can be only forged through the individual overcoming of actual fear. This is why F. Nietzsche utters: "From life's school of war. - What doesn't kill me makes me stronger" (Nietzsche, 2005, p. 157; TI Maxims/8).

While the questions of what kind of dangers we are willing to be confronted with and what kind we are willing to entrust the authority to deal with in an ideal state should be discussed, it should be remembered that we, both as individuals and as humankind, become defenseless before the abandoned danger in the course of time. The ability of an authority to deal with a given set of areas is based on experience and is passed on through state institutions (e.g., laws or bodies). The main problem is that while the authority 'disarms' its citizens with the promise to resolve certain kinds of danger, it never truly succeeds so that it could prevent the given danger not to endanger a disarmed citizen. If this sounds innocuous, it describes the situation of dealing with untrue information accurately.

In the context of untrue information in the social sphere, Rini claims that "individual people typically act reasonably when they grant greater credibility to fellow partisans, even if this sometimes leads to the acquisition of false beliefs" (Rini, 2017), so that this transmission of untrue information often can be reasonable at the individual level. Although Rini does not claim that epistemic partisanship is good in itself, she takes a pessimistic stance in what an individual can control in the given sphere. Thus, Rini sees the solution to the problem of fake news not by "focusing on individual epistemic virtue", but in an "institutional change" (Rini, 2017), i.e., in expecting more control by institutions, e.g., of social media, over spreading 'untrue' information. Arguably, we can find that political-epistemic partisanship and trust, a major determinant of relationships between social subjects, can be reasonable, since we always accept and carry a certain sum of information that is given to us by others. However, trust often becomes ideological gullibility when it comes to politics. The epistemic demands on the individual to successfully orient himself mainly in the social world are increasing with the growing mass of accessible information, and together with advancing democratization they require a change in the epistemic habits of the individual towards a higher suspiciousness when confronting a new piece of information.

Let us suppose that the political-epistemic partisanship can be reasonable, given the shared normative value commitments and a lack of knowledge of the receiving partisan (Rini, 2017). Reasonability itself, however, is an insufficient reason for it to be a moral value, i.e., something worth pursuing while following the good, unless we identify the good solely with rationality, but not with truth. Since the information gained and accepted by a partisan often leads to sharing untrue and manipulative information, it cannot be perceived as good at the ethical level and reliable at the epistemological level. On the other hand, the same issue can also be brought up in individualistic epistemology, if we presuppose a broad, actual, and reliable approach of each epistemic individual consistent with the individual's cognitive functions. Reductio ad absurdum, if we expect by a theory that the individual knows everything, we will certainly fail. However, if we presuppose by 
a theory knowledge dependent on the individual's cognitive functions (and all knowledge we dispose of depends on them), then, I believe, it can fulfil the requirement of knowledge, while we can focus on how to perfect cognitive functions in the epistemological sense while following the good.

The notion that " $[\mathrm{t}]$ he advent of widespread and rapid disinformation increases the number of deaths through the proliferation of hoaxes and epistemological confusion" (Palomo, 2021) can itself create epistemological confusion when used as cliché - "[...] disinformation kills" (Palomo, 2021) or "Covid misinformation on Facebook is killing people" (BBC, 2021; US President J. Biden) - it makes a sweeping statement, leaves out the true agent, and makes it a 'statistic'. M. Palomo indicates the role of the individual mainly in his 'epistemological motivation': “This confusion occurs when individuals are incapable of maintaining high-quality criteria of truthfulness once they have received informative elements of an ideological nature. Epistemological confusion is manifested by people granting truthfulness mainly to what they want to be true [...]" (Palomo, 2021). The end of the quote indirectly exposes the fact that the nature of the problem is fundamentally ethical and therefore should be treated as such. At the political level, the diversion of the problem to the epistemological ground leads to the above-mentioned mechanism: information represents a potential danger, an individual fears the danger of other people acting on 'dangerous' information, an individual has no power over other people but through the authority (public or private), the authority assumes the notion of responsibility and acts upon it, ${ }^{13}$ if it succeeds it minimizes the occurrence of the danger which then only rarely meets the individual, if it fails, the individual is on his own. In the political context, the debate over the control of untrue speech quickly leads to the question of 'Who has the authority over what is true and what is not?' and provokes standard liberal issues. Information itself does not carry an innate danger or moral evil. The debate should withdraw from the metaphor and return to ethics.

The identification of the danger of information is a projection of previous experience of causal identification of a given piece of information and the perception of a situation that causes an unpleasant affect in the perceiver, of which the problem is two-fold: the causal link, where we essentially speak of consequences, is strongly at risk of being a mere disguised correlation and by the projection itself, which is fundamentally assigning the given information a moral attribute, the true causal agent is obscured. If the Ministry of Health considered the information about ivermectin to be true, does it make the Ministry in any way morally less responsible?

In general, neurally-based affective mechanisms in mammals follow a simple aim: the affective systems allow the organism to orient itself in its environment by reacting to it which ultimately leads to the increased chance of survival of the organism. An object identified as an external cause of an ongoing affect (e.g., 'I fear the wolf in my immediate proximity since the wolf in my knowledge represents the human experience of wolves violently hunting down prey. The wolf is thus dangerous.') is added a certain surplus value with a specific relevance. The difference (one of many) between affective systems and rationality, of which a healthy adult human is a carrier, is their effective span. While rationality raised humankind from the wilderness to civilizations through planning, organization, and exploring the environment (e.g., through science), the affective systems prepare and compel the affected body to react immediately. Although rationality 'acts' on a set of data that is 'prepared' by the affective systems through the added surplus value of relevance, thus being the 'problem-solver' for affects, it should seem convincing that to rely solely on affective information in long-term decisions is contra-productive in the context of the survival of

\footnotetext{
${ }^{13}$ Speaking of European countries, the state authority depends on popular will (through voting system). The trend in European countries is for a government to usually accept the responsibility to regulate any new area possible.
} 
the organism and/or species. To overcome the compulsion of affects to act on them, one must be confronted with a given affect (i.e., be affected) in a certain dosage. ${ }^{14}$ If the stimulus raises an affect that is overly 'strong', the subject is unfree not to act upon it. A manageable dose of exposure of a given stimulus (thus of an affect) is at such a rate that allows the subject to be free not to act upon it. A challenging dose is at such a rate that allows the subject not to act upon the affect while it pressures the subject to do so. If the urge is strong and yet it is not affirmed by acting on it, the challenge is overcome and the subject is stronger and more free. To be strong and to be free (due to the nature of a given organism, i.e., to be free is to fulfill one's potential) is the ultimate aim of any living organism. Upon this goal, we create a society to secure human enhancement through creating optimal conditions. As Nietzsche puts it: "[...] everything evil, terrible, tyrannical, predatory, and snakelike in humanity serves just as well as its opposite to enhance the species 'humanity"' (Nietzsche, 2002, p. 41; BGE I/44).

The notion of security can therefore be treacherous: absolute security means absolute elimination of danger. Human enhancement requires a challenge so that by overcoming one enhances himself in accordance to his nature. A challenge requires such stimuli that make the overcoming possible. Perhaps paradoxically, the elimination of danger does not suppress the affective systems - rationality removes the stimuli causing fear and the fear seeks stimuli of what to be feared. By elimination of all sorts of natural danger, the character of the object of fear has shifted to a significant extent to the social sphere. The most danger a European citizen encounters is represented by the object of 'others'. By achieving a state of safety, the affected polis is heading to become weaker. A strong (free) individual is condemned to be surrounded by danger: "That is the yielding of the greatest: it is hazard and danger and casting dice for death" (Nietzsche, 1978, $p$. $115 ; \mathrm{Z} \mathrm{II}){ }^{15}$ If the desire of a human/humankind to become 'stronger' is valid then safety is of secondary importance.

Arguably, if those patients, who were voluntarily treated by ivermectin in prevention of or during COVID-19, were prevented from the obtainment of the information mentioned in the introduction of the paper (if it was possible), they would not endanger their health as a consequence. However, the subjects, represented by the patients, will remain susceptible to similar instances of exposure to 'dangerous' information, i.e., they remain weak. This is not to say that one should act based on a random set of information. On the contrary, one should act on information only if he/she considers the perspective in which the given set of information is manifested to be the most valid, while acting on ethical-epistemological obligation to obtain more perspectives (i.e., aim for wisdom, strength), which was explained in the introduction to the paper.

\section{The Apollonian and the Dionysian}

The philosophical concepts of the Apollonian and the Dionysian represent the duality of order, clarity, and individuation, on the side of Apollo, and chaos, emotion, and unity, on the side of

\footnotetext{
${ }^{14}$ The human particularity allows himself to handle fear (or any affect for that matter) not only actively (i.e., being affected) but also (and perhaps mainly) through the forms (ideas) of affects. I argue that while being able to think of a given affect, there is no need (or possibility) to counteract the affect since it is in its formal 'stage'. The formal thought allows the mind to prepare for the effect of the affect (to a limited extent), but the overcoming itself must take place while being affected.

${ }^{15}$ See also Nietzsche (1968, pp. 501-503; WP 957). For a more detailed study on danger in Nietzsche's ethics see Kuehne (2018).
} 
Dionysus. ${ }^{16}$ Being the two fundamental forces (or 'drives'), their influence is mutually dependent. ${ }^{17}$ In The Birth of Tragedy, Nietzsche criticizes the shift in the Ancient Greek art from equilibrious fusion of the Apollonian and the Dionysian to the side of the Apollonian (Nietzsche, 2000; BT). The primary affective reaction to the unknown is fear and it can be argued that fear of the unknown is a/the fundamental fear, or even that the unknown is the fundament of fear. ${ }^{18}$ Apollo fears the chaotic unknown of Dionysus (who as unindividualized is not in-formation) and reacts to the fear by the 'light' of order and clarity. A state of things biased in favor of Apollo heads to an absolute organization and elimination of chaos. In an absolute Apollonian state, the only dynamics left is the process of individuation which could be seen as the process of an infinite division. Apollo's end is in endless stagnation and the end of Dionysus is in absolute chaos.

In 2005, the World Health Organization published International Health Regulations, and in 2013, the Official Journal of the European Union released Decision No 1082/2013/EU, which called on EU states to develop national plans for pandemic management. ${ }^{19}$ In 2019/2020, most European states abandoned these procedures and started to prepare new ones, more suitable and relevant to the situation of COVID-19 pandemics. The endeavor to contain all danger, be it immediate or even potential, as this shows, through order and safety, expresses the Apollonian will not to be 'controlled' by chaos (Dionysus). However well the plans were prepared, being created under a projection of possible (imaginary) danger they could not anticipate the reality. This only shows that the Apollonian force cannot possibly cover the complexity of reality (i.e., chaos, in the epistemological sense) and therefore is not an exclusively reliable approach to danger.

Nietzschean ressentiment, in short, means the process of externalization (projection) of one's weakness into an external enemy, who is in essence imaginary, for the purpose of freeing ego from the burden of self-conscience. An unpleasant affect emerging from a sense of inferiority (weakness) seeks its object outside the subject. It is the inverting of values as a consequence of vengeful reaction of those who realize they are not masters (Nietzsche, 2009, pp. 53-59; GM II/8-11). Fear, as any negative affect, can and does produce ressentiment in various shapes, one of which is the need to surrender the unpleasant affect (fear of danger) into the hands of authority. The goal is a feeling of 'safety', undisturbedness - pleasure (Nietzsche, 2002, pp. 40-42; BGE 44). In this sense, both 'irrational' distrust of authorities (scientific or political) which we are dealing with today in the context of vaccination, and 'rational' endeavor of order are products of reaction to fear, i.e., they arise from fear as a rationalized affect - ressentiment.

The current pandemic, comprising every affected field of human life, amplified the flaws of the social-political setup. The significance of the individual made another step towards the background in favor of society as a whole in the name of 'public good'. The shift is lubricated by transferring the focus of the popular narrative from the agent to 'information'. In this focus, no particular individuals endangered their health, but information, and as such is perceived as dangerous. The individual in this scenario is a passive carrier and actor of dangerous information.

\footnotetext{
${ }^{16}$ See Nietzsche (2000; 2013); Schopenhauer (2016) (especially the third book: The World as Presentation - The Platonic Idea: The Object of Art). See also Nussbaum (1999); Soll (2013); Thornton (2018).

${ }^{17}$ Nietzsche described the concepts variously as drives, forces, impulses, and powers. The substantial ontological force for Nietzsche is the will to power. The concepts of the Apollonian and the Dionysian should therefore be understood as epistemological foundations rather than ontological ones, i.e., they are 'higher' drives that one submits himself to. They do not constitute affects; they rather represent kinds of knowledge.

${ }^{18}$ See Carleton (2016); Panksepp (1998; especially chapter 11: The Sources of Fear and Anxiety in the Brain); Panksepp \& Biven (2012; especially chapter 5: The Ancestral Roots of FEAR).

${ }^{19}$ See World Health Organization (2016) and The European Parliament and the Council of the European Union (2013). For a critique of the documents see Speakman, Burris \& Coker (2017).
} 
Paralyzed by the notion of safety, the individual becomes a 'child' dependent on the 'mother'. By weakening the individual through responsibility transfer, we gamble with the strength of humankind which can and will cost us our future. To be prepared for another catastrophe does not mean eliminating potential danger in the name of Apollo but becoming and being strong as individuals. Hardly anyone would argue that the law or 'plans' are more flexible and reliable than the faculties of the human mind. This crisis derides the calculated social 'preparedness' and mercifully warns us before the Apollonian path we have taken.

\section{Conclusion}

Information about the efficacy and danger of ivermectin, vaccines, masks, tests, and many other similar phenomena emerging due to the current pandemic tend to be considered as causal agents of undesired effects that emerge, e.g., human suffering or death. It attracts the attention of mainstream social discourse, which tends to aim for simple solutions. The current discourse on the danger of information in epistemology and ethics makes effort to cope with both the public mainstream discourse and the phenomena emerging from the current situation.

Based on the study of the relationship between existence and information, it was demonstrated that the epistemic subject is epistemologically limited. This limitation appears not only in the quantity of information the epistemological can dispose of, but also, and mainly, that the epistemic subject has only a secondary access to the world. For assessment of validity of information, it is necessary to view a given piece of information in the perspective of inter-related information. Although it is not possible for the epistemic subject to assess the validity of a given perspective in relation to existence as such, it is possible to compare a perspective to another. In this way, it can be viewed as epistemologically and ethically good to aim for obtaining perspectives of high quality.

Based on our study regarding information and epistemic subject, the notions of misinformation, disinformation, and fake news have been examined with the focus on intent to deceive and disregard for truth, by which the terms tend to be defined. If we look for solutions, we should understand that we are unable to obtain true knowledge about moral intentions and the relationship to the truth of the originators of a given set of information. For this reason, the paper focused on how one receives information.

It has been argued that to be strong means to fulfill one's potential (especially of the mind), i.e., to become free. To grow in strength requires being exposed to challenges. Overcoming challenges (i.e., courage) demands the full engagement of the body and the mind of the exposed individual (i.e., strength). Freedom, not understood as mere chaos (Dionysus), requires both an idea of unfreedom, which fundamentally constitutes 'anxiety' (or 'angst'), and a certitude of one's self in his own faculties (i.e., wisdom). Courageous wisdom is thus a fulfillment of one's potential and there is nothing more active, reliable, and complete the human mind can achieve. Fear, a natural and useful neural reaction to environment's stimuli, should be treated with a cautious distance. There is an evident gap between the fear reaction and the moral notions of what is desired in the social sphere. To act upon the unpleasant affect of fear is to evade experiencing pain through ressentiment by relinquishing the faculties of dealing with danger. By surrendering the danger into the hands of authority, one does not avoid danger and fear of danger but rather substitutes the character of the kinds of danger one encounters. The notion of authoritative security is therefore not only a misanthropic stance fundamentally based on fear of others, but more importantly, it limits the individual's natural potential to grow stronger. This warning should challenge our vision of an ideal social-political state of things in which we desire to realize our lives.

Undoubtedly, the ivermectin boom, downplaying coronavirus, and untrue information spread about vaccination and treatment can represent a kind of informational danger. With the focus on 
the content of information and motives of its creation, it is fundamentally the problem of untruthfulness. Lies and deception represent a danger older than human languages. However, the giant leap towards the control of speech as such indicates a rather naive view both of humans and truth. In a sterile and safe world, where only truth is allowed to be spoken, the strongest are those who lie. If we took a step back from the 'unquestionable' call to action, it would allow us to see the motives of our action. Not the fact that we fear fear, but that we fear fear shows us that we cannot escape fear while acting upon fear itself. By affirming fear through fear of fear, we not only stagnate in it, but we actively expand its 'tentacles'. Even more, by successfully eliminating any given danger - neither danger as such nor fear as such diminishes. Whether we take on the Sisyphean curse of establishing safety or not, this should be understood: the only possible means of truly overcoming danger posited by information is through the mind of an individual, and the only authority of truth is reality.

\section{References}

ANSCOMBE, G. E. M. (1957/2000): Intention. Cambridge, MA: Harvard University Press. ARISTOTLE (2004): Nicomachean Ethics. Cambridge: Cambridge University Press.

BAYNE, T. \& MONTAGUE, M. (2011): Cognitive phenomenology. Oxford: Oxford University Press.

BBC (2021): Covid misinformation on Facebook is killing people - Biden. In: BBC News, July 17, 2021 [online] [Retrieved August 20, 2021]. Available at: https://www.bbc.com/news/world-uscanada-57870778

BRENTANO, F. (1874/2015): Psychology from an empirical standpoint. London \& New York: Routledge.

CARLETON, R. N. (2016): Fear of the unknown: One fear to rule them all? In: Journal of Anxiety Disorders, 41, pp. 5-21.

CONSTINE, J. (2017): Facebook has now 2 billion monthly users...and responsibility. In: TechCrunch, June 27, 2017 [online] [Retrieved August 18, 2021]. Available at: https://techcrunch.com/2017/06/27/facebook-2-billion-users

CRANE, T. (1998): Intentionality as the mark of the mental. In: Royal Institute of Philosophy Supplements, 43, pp. 229-251.

CRANE, T. (2009): Intentionalism. In: B. P. McLaughlin, A. Beckermann \& S. Walter (eds.): The Oxford handbook of philosophy of mind. New York: Oxford University Press, pp. 474-493.

DENNETT, D. C. (1987): The intentional stance. Cambridge, MA: The MIT Press.

DENTITH, M. R. X. (2016): The problem of fake news. In: Public Reason, 8(1-2), pp. 65-79.

ELGAZZAR, A. et al. (2020/2021): Efficacy and safety of Ivermectin for treatment and prophylaxis of COVID-19 pandemic (Preprint) [online] [Retrieved November 5, 2021]. Available at: https://www.researchsquare.com/article/rs-100956/v3

EUROPEAN COMMISSION (2017): Next step against fake news: Commission sets up High-Level Expert Group and launches public consultation [press release], November 13, 2017 [online] [Retrieved August 21, 2021]. Available at: https:/ec.europa.eu/commission/presscorner/ detail/en/IP $17 \quad 4481$

EUROPEAN COMMISSION (2021): Tackling online disinformation [online] [Retrieved August 21, 2021]. Available at: https://digital-strategy.ec.europa.eu/en/policies/online-disinformation EUROPEAN MEDICINES AGENCY (2021): EMA advises against use of ivermectin for the prevention or treatment of COVID-19 outside randomised clinical trials, March 22, 2021 [online] [Retrieved November 5, 2021]. Available at: https://www.ema.europa.eu/en/news/ema-advisesagainst-use-ivermectin-prevention-treatment-covid-19-outside-randomised-clinical-trials 
FALLIS, D. (2015): What is disinformation? In: Library Trends, 63(3), pp. 401-426.

FALLIS, D. \& STOKKE, A. (2017): Bullshitting, lying, and indifference toward truth. In: Ergo: An Open Access Journal of Philosophy, 4(10), pp. 277-309.

FRANKFURT, H. G. (2005): On bullshit. Princeton: Princeton University Press.

GELFERT, A. (2018): Fake news: A definition. In: Informal Logic, 38(1), pp. 84-117.

GELFERT, A. (2021): Fake news, false beliefs, and the fallible art of knowledge maintenance. In:

S. Bernecker, A. K. Flowerree \& T. Grundmann (eds.): The epistemology of fake news. Oxford: Oxford University Press, pp. 310-333.

GOLEMAN, D. (2005): Emotional intelligence: Why it can matter more than IQ. New York: Random House.

GRICE, H. P. (1957): Meaning. In: Philosophical Review, 66(3), pp. 377-388.

GRICE, H. P. (1975): Logic and conversation. In: P. Cole \& J. L. Morgan (eds.): Syntax and semantics. Leiden: Brill, pp. 22-40.

HOWARD, P. (2020): Misinformation and the coronavirus resistance. In: Oxford Internet Institute, University of Oxford, April 24, 2020 [online] [Retrieved August 20, 2021]. Available at: https://www.oii.ox.ac.uk/blog/misinformation-and-the-coronavirus-resistance/

IDONIJE, O. B. et al. (2011): Effects of Ivermectin therapy on the sperm functions of Nigerian onchocerciasis patients. In: Archives of Applied Science Research, 3(3), pp. 533-543.

JASTER, R. \& LANIUS, D. (2021): Speaking of fake news: Definitions and dimensions. In: S. Bernecker, A. K. Flowerree \& T. Grundmann (eds.): The epistemology of fake news. Oxford: Oxford University Press, pp. 20-45.

JUNG, C. G. (2004): Four archetypes: Mother, Rebirth, Spirit, Trickster. London \& New York: Routledge Classics.

KUEHNE, T. (2018): Nietzsche's ethics of danger. In: Journal of Nietzsche Studies, 49(1), pp. 78101.

LEITER, B. (1994): Perspectivism in Nietzsche's Genealogy of morals. Berkeley: University of California Press.

LOEWER, B. (1987): From Information to Intentionality. In: Synthese, 70(2), pp. 287-317.

MEDPAGE TODAY (2021): Large Ivermectin Study Retracted, July 20, 2021 [online] [Retrieved November 5, 2021]. Available at: https://www.medpagetoday.com/specialreports/exclusives/93658

MINER, R. (2017): Nietzsche and Montaigne. London: Palgrave Macmillan.

Ministry of Health of the Slovak Republic (2021a): Dnes očakávame dodanie tisícok dávok lieku Ivermektin [We expect a delivery of thousands of doses of ivermectin today], February 19, 2021 [online] [Retrieved November 5, 2021]. Available at: https://www.health.gov.sk/Clanok?covid-1919-02-2021-lieky

Ministry of Health of the Slovak Republic (2021b): Minister zdravotnictva povolil d'alśi dovoz liekov na liečbu COVID-19 [The Minister of Health has authorized further imports of drugs for the treatment of COVID-19], February 22, 2021 [online] [Retrieved November 5, 2021]. Available at: https://www.health.gov.sk/Clanok?covid-19-22-02-2021-lieky

NIETZSCHE, F. (1885/1978): Thus spoke Zarathustra. New York: Penguin Books.

NIETZSCHE, F. (1886/2002): Beyond good and evil. New York: Cambridge University Press. NIETZSCHE, F. (1887/1989): On the genealogy of morals and Ecce Homo. New York: Vintage. NIETZSCHE, F. (1888/2005): Anti-Christ, Ecce Homo, Twilight of the idols. Cambridge: Cambridge University Press.

NIETZSCHE, F. (1928/2013): The Dionysian vision of the world. Minneapolis: Univocal Publishing. 
NIETZSCHE, F. (1968): The will to power. New York: Random House, Inc.

NUSSBAUM, M. C. (1999): Nietzsche, Schopenhauer, and Dionysus. In: Ch. Janaway (ed.): The Cambridge companion to Schopenhauer. Cambridge: Cambridge University Press, pp. 344-374. PALOMO, M. (2021): How disinformation kills: Philosophical challenges in the post-Covid society. In: History and Philosophy of the Life Sciences, 43(2), pp. 1-5.

PANKSEPP, J. \& BIVEN, L. (2012): The archeology of mind. Neuroevolutionary origins of human emotion. New York \& London: W. W. Norton \& Company.

PANKSEPP, J. (1998): Affective neuroscience: The Foundations of human and animal emotions. New York: Oxford University Press.

PERRY, J. (1994): Intentionality and its puzzles. In: S. D. Guttenplan (ed.): A companion volume to the philosophy of mind. Oxford: Blackwell, pp. 386-395.

PETRUFOVÁ JOPPOVÁ, M. (2022): Od patetiky $k$ etike [From pathetics to ethics], forthcoming. PREMACK, D. \& WOODRUFF, G. (1978): Does the chimpanzee have a theory of mind? In: Behavioral and Brain Sciences, 1(4), pp. 515-526.

PRITCHARD, D. (2021): Good news, bad news, fake news. In: S. Bernecker, A. K. Flowerree \& T. Grundmann (eds.): The epistemology of fake news. Oxford: Oxford University Press, pp. 46-67. REMHOF, J. (2015): Nietzsche's conception of truth: Correspondence, coherence or pragmatist? In: The Journal of Nietzsche Studies, 46(2), pp. 229-238.

RINI, R. (2017): Fake news and partisan epistemology. In: Kennedy Institute of Ethics Journal, 27(S2), pp. 43-64.

SCHOPENHAUER, A. (1819/2016): The world as will and presentation, vol. I. Abingdon \& New York: Routledge.

SØE, S. O. (2019): A unified account of information, misinformation, and disinformation. In: Synthese, 198(11), pp. 5929-5949.

SOLL, I. (2013): Schopenhauer as Nietzsche's "Great Teacher" and "Antipode". In: J. Richardson \& K. Gemes (eds.): The Oxford handbook of Nietzsche. New York: Oxford University Press, pp. 160-184.

SPEAKMAN, E. M., BURRIS, S. \& COKER, R. (2017): Pandemic legislation in the European Union: Fit for purpose? The need for a systematic comparison of national laws. In: Health Policy, 121(10), pp. 1021-1024.

THE CENTERS FOR DISEASE CONTROL AND PREVENTION (2021): Rapid increase in Ivermectin prescriptions and reports of severe illness associated with use of products containing ivermectin to prevent or treat COVID-19, August 26, 2021 [online] [Retrieved November 5, 2021]. Available at: https://emergency.cdc.gov/han/2021/pdf/CDC_HAN_449.pdf

THE EUROPEAN PARLIAMENT AND THE COUNCIL OF THE EUROPEAN UNION (2013): Decision No 1082/2013/EU of the European Parliament and of the Council of 22 October 2013 on serious cross-border threats to health and repealing Decision No 2119/98/EC, November 5, 2013 [online] [Retrieved August 18, 2021]. Available at: https://ec.europa.eu/health/sites/default/files/ preparedness_response/docs/decision_serious_crossborder_threats_22102013_en.pdf

THORNTON, R. W. (2018): Belonging, Possession and the Ironic Life Force: Philosophical Synthesis in the Early Period Plays of Eugene O'Neill. Santa Barbara: University of California.

TV MARKÍZA (2021): Začínajú sa množit' pacienti, ktorí sa predávkovali ivermektínom. Tieto prejavy sú najčastejšie [Patients who have overdosed on ivermectin are starting to increase in number. These symptoms are the most common], March 18, 2021 [online] [Retrieved November 5, 2021]. Available at: https://www.tvnoviny.sk/koronavirus/2023442_zacinaju-sa-mnozit-pacientiktori-sa-predavkovali-ivermektinom-tieto-prejavy-su-najcastejsie 
USA TODAY (2001): Fact check: Claim that ivermectin causes male sterility is based on deeply flawed study, September 15, 2021 [online] [Retrieved November 7, 2021]. Available at: https://eu.usatoday.com/story/news/factcheck/2021/09/15/fact-check-false-claim-ivermectincauses-sterility-85-men/8319553002/

WORLD HEALTH ORGANIZATION (2016): International health regulations (2005), Third Edition. Geneva: World Health Organization.

ZÁKON Č. 300/2005 Z.z. Trestný zákon, v znení neskorších predpisov [Act No. 300/2005 Coll. the Criminal Code, as amended].

ZALTA, E. (1988): Intensional logic and the metaphysics of intentionality. Cambridge, MA: The MIT Press.

ZEM \& VEK (2021): Vedci objavili dostupný liek na covid, podla štúdie znižuje riziko úmrtia o $80 \%$, January 12, 2021 [online] [Retrieved November 5, 2021]. Available at: https://zemavek.sk/vedci-objavili-dostupny-liek-na-covid-podla-studie-znizuje-riziko-umrtia-o80/

ZIMMERMAN, F. \& KOHRING, M. (2018): "Fake News" als aktuelle Desinformation. Systematische Bestimmung eines heterogenen Begriffs ["Fake News" as Current Disinformation: A Systematic Definition of a Heterogeneous Term]. In: $M \& K$ Medien \& Kommunikationswissenschaft, 66(4), pp. 526-541. 